\title{
DETERMINATION OF ADRENERGIC AND CHOLINERGIC SUBSTANCES IN THE BLOOD OF MAN ${ }^{1}$
}

\author{
By MARC J. MUSSER AND ELIZABETH A. GRIMM \\ (From the Department of Internal Medicine, University of Wisconsin Medical School, Madison)
}

(Received for publication August 2, 1948)

Much has been written about the clinical manifestations which indicate disturbances in function of the autonomic nervous system in numerous disease processes. Various clinical signs are identified with orthosympathetic or parasympathetic predominance. Autonomic drugs are used diagnostically and therapeutically, and surgical procedures have been devised which temporarily or permanently interrupt the neurogenic influences of this system upon the various parts of the body. Yet, consistently lacking have been objective tests which might indicate the nature or degree of existing autonomic disturbances. The availability of such tests would materially facilitate an evaluation of the importance of the autonomic nervous system in such diseases as thyrotoxicosis, peptic ulcer, hypertension, bronchial asthma, and a large number of the neuropsychiatric disorders.

Current concepts of the mediation of autonomic nervous system effects include humoral mechanisms. Investigation of the latter was the object of this study.

The well known responses of isolated rabbit intestine to epinephrine and acetylcholine have made possible its use as a method of identification of these substances in various solutions, including blood. The marked sensitivity and the relative specificity of the adrenergic response (1) as well as the simplicity of the method make it the best of the biologic tests for this substance so far developed. The cholinergic response is equally sensitive but much less specific since many substances besides acetylcholine cause an increase in the tone and contraction of the gut by their action upon the parasympathetic ganglion cells in the walls of the muscle $(2,3)$.

Isolated rabbit duodenum was used by Milhorat, Small, Doty and Bartels (4) and Diethelm, Doty and Milhorat (5) to assay the blood of patients with emotional disturbances for adrenergic

1 This study was made possible by a grant from the S. G. Heath Fund. and cholinergic substances. They concluded that anxiety, resentment, and anger appeared to be accompanied by adrenergic factors in the blood while tension and possibly fear were accompanied by cholinergic factors. Furthermore their results indicated no essential difference between normal and psychopathological emotions except in the intensity of adrenergic and cholinergic responses.

If it is true that adrenergic and cholinergic substances can be demonstrated in the blood of healthy individuals, one might expect qualitative or quantitative differences of these substances in patients with diseases which are accompanied by evidence of disturbed autonomic function. In addition, autonomic nervous system surgery might be expected to alter these circulating substances, especially if the humoral mechanism of autonomic effect is significant. Two circumstances are recognized, however: 1 . the human organism is capable of maintaining a remarkably fine humoral balance under normal and some abnormal conditions, and 2 . humoral influences are effected not only by the amount of a circulating material but also by the ability of a tissue to respond to it.

\section{PROCEDURE}

Rabbits were killed by the injection of air into an ear vein. The intestine was cut at the pylorus and about $10 \mathrm{~cm}$. of the duodenum removed. After thorough washing a piece $1.5 \mathrm{~cm}$. in length was placed in $200 \mathrm{cc}$. of Ringer-Tyrode solution maintained at a temperature of $36^{\circ}$ to $38^{\circ} \mathrm{C}$ by a thermostatically controlled water bath. The solution was stirred gently by a stream of air. A recording lever was attached to one end of the muscle and the contractions were recorded on a kymograph. The sensitivity of the preparation to epinephrine and acetylcholine was determined by the addition to the solution of these drugs in varying amounts by means of long screwcontrolled pipettes. An amount was chosen which would give consistently a decisive but not prolonged effect. For acetylcholine this meant a concentration of $1: 200$,000,000 to $1: 50,000,000$; for epinephrine it varied from $1: 100,000,000$ to $1: 16,000,000$. The acetylcholine was added first, followed by the epinephrine, after which the preparation was washed and resuspended in fresh Ringer- 


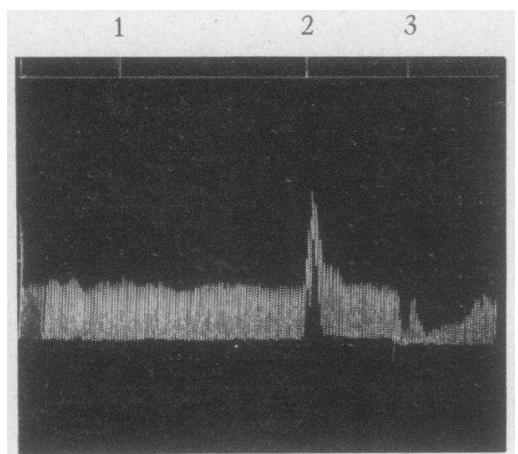

FIG. 1

1. Blood from normal male added-negative response.

2. 0.15 cc. $\mathrm{ACH}, 1: 10,000$ added.

3. 0.12 cc. EPH, $1: 10,000$ added.

Tyrode solution. If epinephrine was added to a preparation repeatedly without changing the Ringer-Tyrode solution, the sensitivity of the tissue decreased with each successive application until finally the contractions continued with the usual amplitude and frequency despite the addition of the drug. If, however, the tissue was then washed and resuspended in fresh solution, it again responded with its original sensitivity. This change in sensitivity with repeated applications of the drug has been noted by Hoskins (1) and Bernheim (6) although neither offered an explanation for the phenomenon.

When the response of the preparation to known solutions of epinephrine and acetylcholine was determined, blood specimens were tested as follows. The blood was drawn from the patient's median cubital vein into a syringe moistened with heparin and within three to 10 minutes was added to the fresh Ringer-Tyrode solution in which the muscle was suspended. After the effect of the blood was recorded, known amounts of epinephrine and acetylcholine were added to this solution to test the tissue sensitivity. Thereafter, the tissue was again washed and suspended in fresh Ringer-Tyrode preparatory for

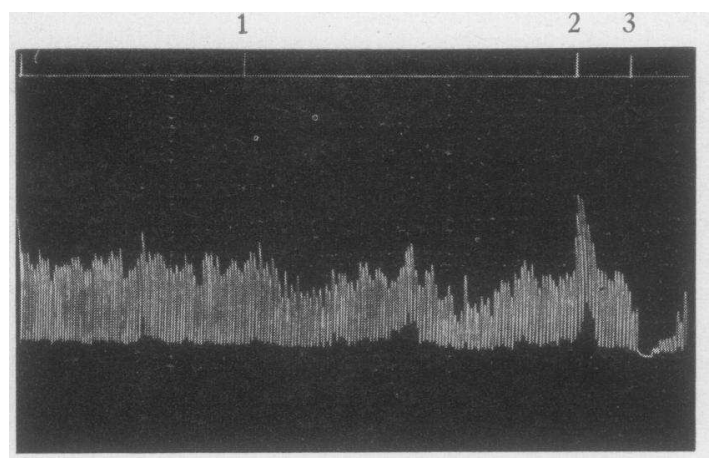

FIG. 2

1. Blood from normal male added-indeterminate response.

2. 0.02 cc. ACH, $1: 10,000$ added.

3. 0.02 cc. EPH, $1: 10,000$ added. another test. It was possible to use most muscle preparations for four to six hours with no significant change in their response to the known amounts of epinephrine and acetylcholine. In some instances, in addition to the whole blood sample, blood was centrifuged, separated, and the plasma and cells tested separately. In these latter experiments, there was an interval of 35 to 45 minutes between the drawing of the blood and the addition of the separate constituents. Test solutions of varying concentrations of pitressin were also used.

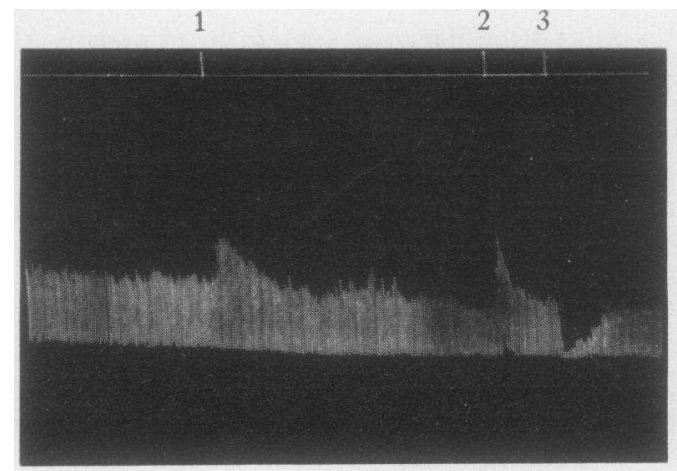

FIG. 3

1. Blood from normal male added-CHO (2) response. 2. 0.04 cc. ACH, $1: 10,000$ added.

3. 0.04 cc. EPH, $1: 10,000$ added.

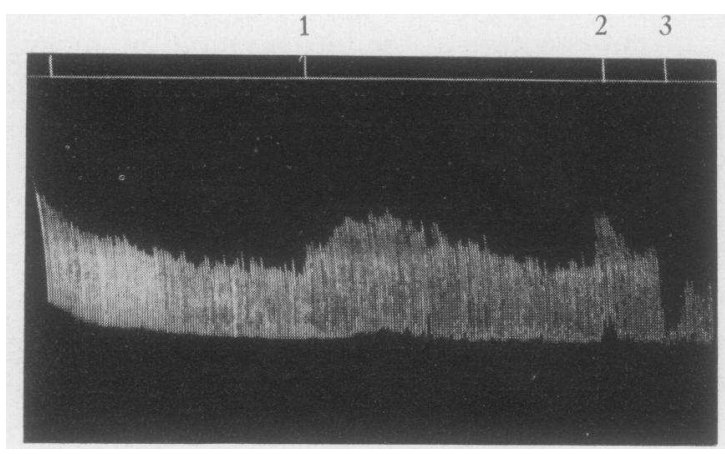

FIG. 4

1. Blood from hypertensive female added-prolonged $\mathrm{CHO}$ effect.

2. 0.04 cc. ACH, $1: 10,000$ added.

3. 0.04 cc. EPH, $1: 10,000$ added.

Responses were recorded as follows: "cholingergic" ( $\mathrm{CHO})$, meaning an increase in muscle tone and amplitude of contraction; "adrenergic" (ADR), meaning a decrease in tone and amplitude of contraction; "Negative" (NEG), if no change was noted; and "indeterminate" (I), when the change was bizarre and neither definitely cholinergic nor adrenergic. The degree of response was recorded as 1 . (less than), 2. (equal to), and 3. (more than) the response of the tissue to known amounts of acetylcholine and epinephrine. 


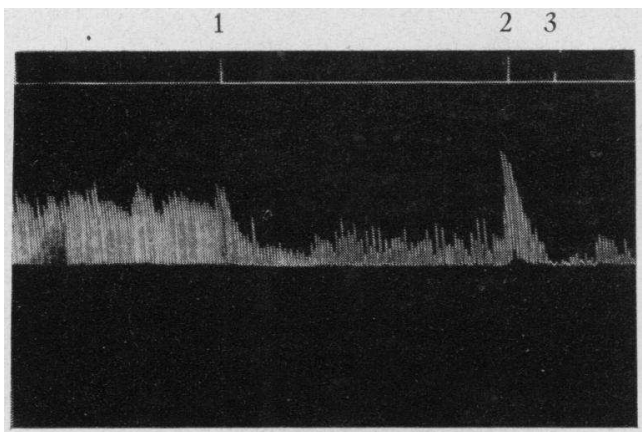

FIG. 5

1. Blood from male with ulcerative colitis added-prolonged ADR effect.

2. 0.04 cc. ACH, 1: 10,000 added.

3. 0.08 cc. EPH, $1: 10,000$ added.

Responses which did not occur within 25 seconds after the addition of the blood were considered "delayed" (D), and those persisting more than five minutes were considered "prolonged" (P). In no instances did responses to known amounts of the pure drugs persist longer than one minute.

In some instances the response was at first cholinergic and then adrenergic. This is so indicated by an arrow in the tables of results. Examples of the various responses are shown in Figures 1 through 7.

The types of cases studied are listed in Table I. Controls consisted of members of the hospital staff and were engaged in essentially the same duties. All were well known and were felt to be emotionally stable. Each was questioned regarding the existence of any particular or excessive emotional reaction existing at the time the blood sample was taken. Patients were selected as typical and clear-cut examples of the illnesses from which they suffered. Those with emotional disturbances had chronic anxiety tension reactions which varied but little from day to day. In each instance, at the time of testing, none was experiencing any acute or unusual emotional reaction.

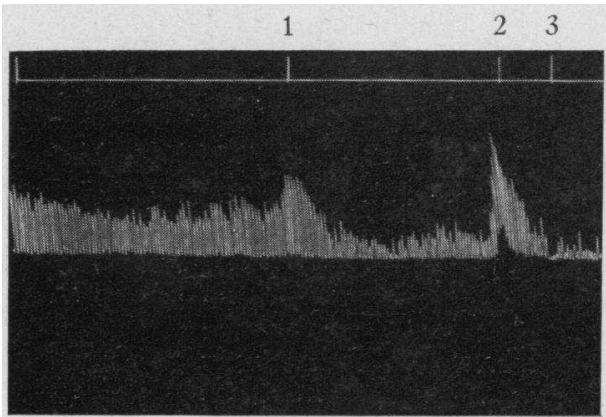

FIG. 6

1. Blood from female with asthma added-CHO effect followed by ADR effect.

2. 0.04 cc. $\mathrm{ACH}, 1: 10,000$ added.

3. 0.08 cc. EPH, $1: 10,000$ added.

TABLE I

Types of cases studied

\begin{aligned} 20 & Normals \\ 3 & Ulcerative colitis \\ 3 & Peptic ulcer \\ 3 & Asthma \\ 8 & Thyrotoxicosis \\ 11 & Anxiety-tension state \\ 1 & Schizophrenia \\ 1 & Involutional melancholia \\ 8 & Essential hypertension \\ \hline 58 & Total \end{aligned}

Morning and afternoon blood specimens were drawn two to three hours after food ingestion and in the majority of cases were taken on the same day.

\section{RESULTS}

The response of the muscle strip to whole blood from normal subjects (Tables II and III) was varied and highly irregular, both in the group as a

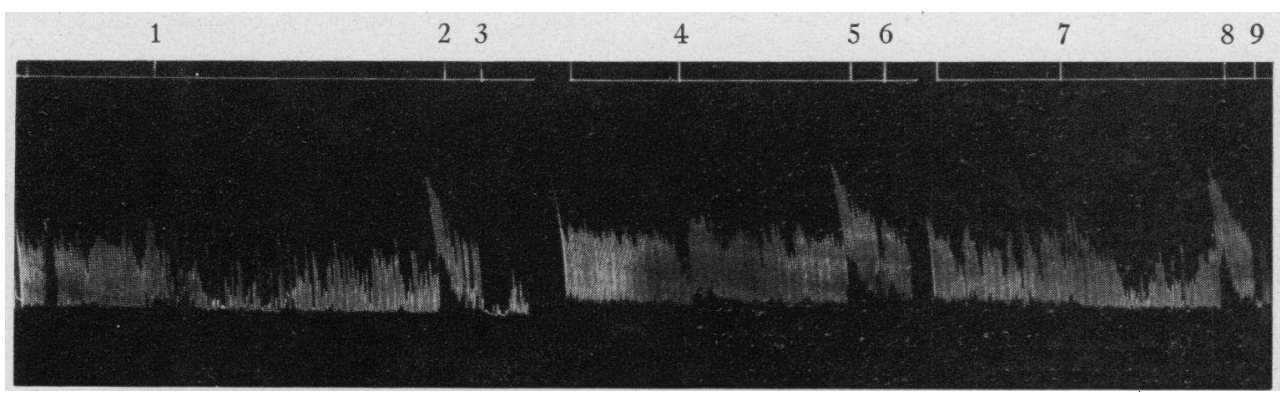

FIG. 7

1. Whole blood from male hypertensive (post-sympathectomy) added-response indeterminate.

2, 5, and 8. $0.04 \mathrm{cc}$. ACH, $1: 10,000$ added.

3, 6, and 9. 0.12 cc. EPH, $1: 10,000$ added.

4. Plasma of same blood added-ADR followed by $\mathrm{CHO}$ response.

7. Cells from same blood added-ADR response. 
TABLE II

Response of muscle to whole blood of normals

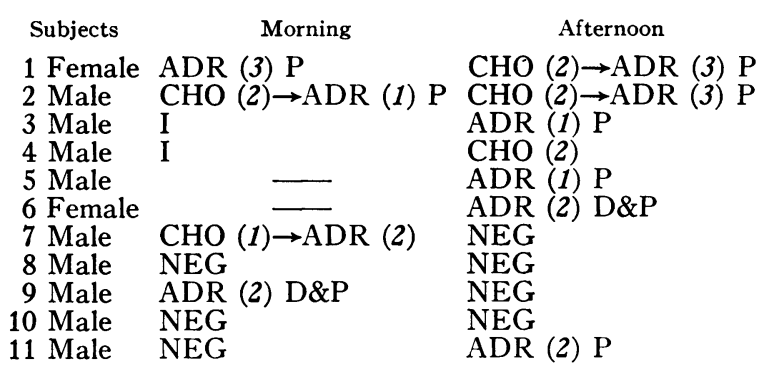

whole and in the individual subject. This is especially apparent in the morning and afternoon samples tested on consecutive days. Types of response could not be correlated with any particular environmental situation, physical state, or minor emotional reaction arising during the course of the subject's daily hospital duties.

No consistent responses were observed when whole blood, plasma, or cells were tested separately (Table IV and Figure 7). Cannon (7) reported that serum and whole blood would cause the same shortening when added to the muscle strip. Mil-

TABLE III

Response of muscle to whole blood of normals on successive days

\begin{tabular}{|c|c|c|c|}
\hline Subjects & Day & Morning & Afternoon \\
\hline 12 Male & $\frac{1}{2}$ & NEG & $\begin{array}{l}\operatorname{ADR}(2) P \\
A D R \\
\text { (1) }\end{array}$ \\
\hline 13 Female & $\begin{array}{l}1 \\
2\end{array}$ & $\begin{array}{l}\text { NEG } \\
\text { NEG }\end{array}$ & $\begin{array}{l}\operatorname{ADR}(2) \mathrm{P} \\
\operatorname{ADR}(1) \mathrm{P}\end{array}$ \\
\hline 14 Male & $\begin{array}{l}1 \\
2 \\
3\end{array}$ & $\operatorname{ADR}(1) \overline{\bar{P}}$ & $\begin{array}{l}\text { NEG } \\
\text { NEG } \\
\text { ADR (1) P }\end{array}$ \\
\hline 15 Female & $\begin{array}{l}1 \\
2\end{array}$ & $\begin{array}{l}\mathrm{ADR}(1) \stackrel{\mathrm{P}}{\mathrm{CHO}}(1) \rightarrow \mathrm{ADR}(1) \mathrm{P}\end{array}$ & $\operatorname{ADR}(2) \mathrm{P}$ \\
\hline 16 Male & $\begin{array}{l}1 \\
2\end{array}$ & $\begin{array}{l}\text { ADR } \\
\text { NEG }\end{array}$ & $\operatorname{ADR}(1) \bar{P}$ \\
\hline 17 Male & 1 & $\mathrm{CHO}(2) \overline{\rightarrow \mathrm{ADR}}(2) \mathrm{P}$ & $\begin{array}{l}\mathrm{CHO}(1) \\
\mathrm{CHO} \\
(1) \rightarrow \mathrm{CHO}(3) \mathrm{P}\end{array}$ \\
\hline 18 Male & $\begin{array}{l}1 \\
2 \\
3 \\
4 \\
5 \\
6 \\
6 \\
7\end{array}$ & $\begin{array}{l}\mathrm{CHO}(2) \overrightarrow{\rightarrow A D R}(1) \mathrm{P} \\
\mathrm{ADR}(1) \mathrm{D \& P} \\
\mathrm{ADR}(1) \mathrm{D \& P} \\
\mathrm{CHO}(1)\end{array}$ & $\begin{array}{l}\text { NEG } \\
\text { NEG } \\
\text { CHO (1) } \rightarrow \text { ADR (1) } \mathrm{P} \\
\text { CHO (1) D } \\
\text { ADR (2) D }\end{array}$ \\
\hline 19 Male & $\begin{array}{l}1 \\
2 \\
3 \\
4 \\
5 \\
6\end{array}$ & $\begin{array}{ll}\text { I } & = \\
\text { NEG } \\
\text { I }\end{array}$ & $\begin{array}{l}\mathrm{NEG} \\
\text { ADR (1) } \mathrm{D} \\
\mathrm{CHO}(2) \rightarrow \operatorname{ADR}(1) \mathrm{P} \\
\mathrm{ADR}(1) \stackrel{\mathrm{P}}{ } \\
\mathrm{NEG}\end{array}$ \\
\hline 20 Female & $\begin{array}{l}1 \\
2 \\
3 \\
4 \\
5\end{array}$ & $\begin{array}{l}\text { ADR (1) } \mathrm{P} \\
\text { NEG } \\
\text { NEG } \\
\text { NEG }\end{array}$ & $\begin{array}{l}\text { NEG } \\
\text { ADR (1) } \mathrm{P} \\
\text { ADR (1) } \mathrm{P} \\
\text { ADR (1) } \mathrm{P} \\
\text { NEG }\end{array}$ \\
\hline
\end{tabular}

horat et al. (4) stated that the substances in the blood producing the effects they described were labile and would disappear if the blood was allowed to stand 15 to 20 minutes after being drawn. Cannon (7) stated that blood from excited animals which produced inhibition of an intestinal strip lost this power upon standing in the cold for 24 hours or when kept warm and agitated with bubbling oxygen for two to three hours. As can be seen in Table IV, in only two instances did the addition of plasma fail to show an effect upon the muscle even though it was added as long as 30 to 45 minutes after withdrawal of the blood from the subject.

The blood from patients with chronic anxiety tension reactions (Table V) likewise showed considerable irregularity of effect. Morning and afternoon variation was marked; there was no relationship between the type and intensity of the muscle response and the severity of the emotional disorder; and in general, the intensity of the muscle response was less than the response to the solutions of known amounts of acetylcholine and epinephrine. As pointed out above, none of these patients was tested during acute emotional reactions. All exhibited chronic anxiety over their somatic symptoms and existing environmental problems, and were prone to develop excessive tension in response to stress. In the majority of them, psychiatric investigation had demonstrated the presence of deep-seated and repressed resentment and/or fear. With such mixtures of emotional reactions, individually accompanied by adrenergic or cholinergic factors (5), such variability of results as were observed was not unexpected. It is important to note that as a group they produced effects entirely similar to the controls.

One patient with a severe involutional melancholia was tested while she was extremely agitated, fearful, and protesting vehemently against the venipuncture. On one occasion (morning) her blood was adrenergic, on the other (afternoon) it was cholinergic. In each instance, it was impossible to determine the predominate emotional reaction.

Blood of patients suffering from peptic ulcer and ulcerative colitis, diseases in which parasympathetic predominence has been felt to exist, showed adrenergic effects in the majority of tests (Table V). 
TABLE IV

Effect of whole blood, plasma and cells from normal subjects and patients on one or more days

\begin{tabular}{|c|c|c|c|c|}
\hline Subjects & Diagnosis & Day & & \\
\hline \multirow[t]{2}{*}{18 Male } & & 1 & $\begin{array}{l}\text { Blood } \\
\text { Plasma } \\
\text { Cells }\end{array}$ & $\begin{array}{l}\operatorname{ADR}(1) \\
\text { CHO (1) } \\
\operatorname{ADR}(1)\end{array}$ \\
\hline & & 2 & $\begin{array}{l}\text { Blood } \\
\text { Plasma } \\
\text { Cells }\end{array}$ & $\begin{array}{l}\text { NEG } \\
\text { CHO (1) D\&P }\end{array}$ \\
\hline 19 Normal female & & 1 & $\begin{array}{l}\text { Blood } \\
\text { Plasma } \\
\text { Cells }\end{array}$ & $\begin{array}{l}\text { CHO (2) } \rightarrow \text { ADR (1) P } \\
\text { NEG } \\
\text { ADR (1) P }\end{array}$ \\
\hline \multirow[t]{4}{*}{20 Normal male } & & 1 & $\begin{array}{l}\text { Blood } \\
\text { Plasma } \\
\text { Cells }\end{array}$ & $\begin{array}{l}\mathrm{ADR}(1) \mathrm{P} \\
\mathrm{CHO}(2) \mathrm{P} \\
\mathrm{CHO}(2) \rightarrow \operatorname{ADR}(1) \mathrm{P}\end{array}$ \\
\hline & & 2 & $\begin{array}{l}\text { Blood } \\
\text { Plasma } \\
\text { Cells }\end{array}$ & $\begin{array}{l}\mathrm{I} \\
\mathrm{CHO}(2) \mathrm{P} \\
\operatorname{ADR}(1)\end{array}$ \\
\hline & & 3 & $\begin{array}{l}\text { Blood } \\
\text { Plasma } \\
\text { Cells }\end{array}$ & $\begin{array}{l}\text { ADR (2) P } \\
\text { NEG } \\
\text { ADR (1) }\end{array}$ \\
\hline & & 4 & $\begin{array}{l}\text { Blood } \\
\text { Plasma } \\
\text { Cells }\end{array}$ & $\begin{array}{l}\operatorname{ADR}(1) \mathrm{P} \\
\mathrm{ADR}(1) \mathrm{P}\end{array}$ \\
\hline 34 Female & Hypertension & 1 & $\begin{array}{l}\text { Blood } \\
\text { Plasma } \\
\text { Cells }\end{array}$ & $\begin{array}{l}\mathrm{CHO}(2) \\
\mathrm{ADR}(2) \\
\mathrm{I}\end{array}$ \\
\hline 35 Female & Hypertension & 1 & $\begin{array}{l}\text { Blood } \\
\text { Plasma } \\
\text { Cells }\end{array}$ & $\begin{array}{l}\mathrm{CHO}(2) \mathrm{P} \\
\mathrm{ADR}(2) \\
\mathrm{ADR}(1) \rightarrow \mathrm{CHO} \text { (2) } \mathrm{P}\end{array}$ \\
\hline 37 Female & $\begin{aligned} & \text { Hypertension, } \text { preoperative } \\
& \text { postoperative } \\
& \text { postoperative } \\
& \text { postoperative }\end{aligned}$ & & $\begin{array}{l}\text { Blood } \\
\text { Blood } \\
\text { Plasma } \\
\text { Cells }\end{array}$ & $\begin{array}{l}\text { CHO (2) D\&P } \\
\text { I } \\
\text { ADR (3) } \\
\text { ADR (2) D }\end{array}$ \\
\hline 38 Male & $\begin{array}{r}\text { Hypertension, } \\
\text { preoperative } \\
\text { postoperative } \\
\text { postoperative } \\
\text { postoperative }\end{array}$ & & $\begin{array}{l}\text { Blood } \\
\text { Blood } \\
\text { Plasma } \\
\text { Cells }\end{array}$ & $\begin{array}{l}\text { NEG } \\
\text { CHO (1) } \rightarrow \text { ADR (1) } \\
\text { ADR (3) } \\
\text { CHO (1) } \rightarrow \text { ADR }(1)\end{array}$ \\
\hline
\end{tabular}

Blood from bronchial asthma patients was predominately adrenergic in effect, regardless of the severity of symptoms at the time of specimen withdrawal. The type of muscle response-delayed and prolonged-was more consistent in this group than in any other studied. No explanation for this was apparent. All blood samples were drawn at least two hours after any medication. One patient (No. 3), who in addition to asthma had a severe anxiety tension state, could not tolerate epinephrine.

Results from thyrotoxic patients were equally as irregular as the control studies. Degree of toxicity did not seem to be a factor.
Likewise there was considerable variability in the effects of blood taken from patients suffering from essential hypertension. In three cases (Nos. 36,37 , and 38) samples drawn the day before and seven days after thoracolumbar sympathectomy were similarly inconsistent.

In all of the experiments, the response of the muscle strip to blood was frequently prolonged and in this respect differed considerably from the response to solutions of acetylcholine and epinephrine.

\section{DISCUSSION}

The data obtained allow for no conclusions regarding the status of the autonomic nervous sys- 
TABLE $V$

Response of muscle to whole blood of patients

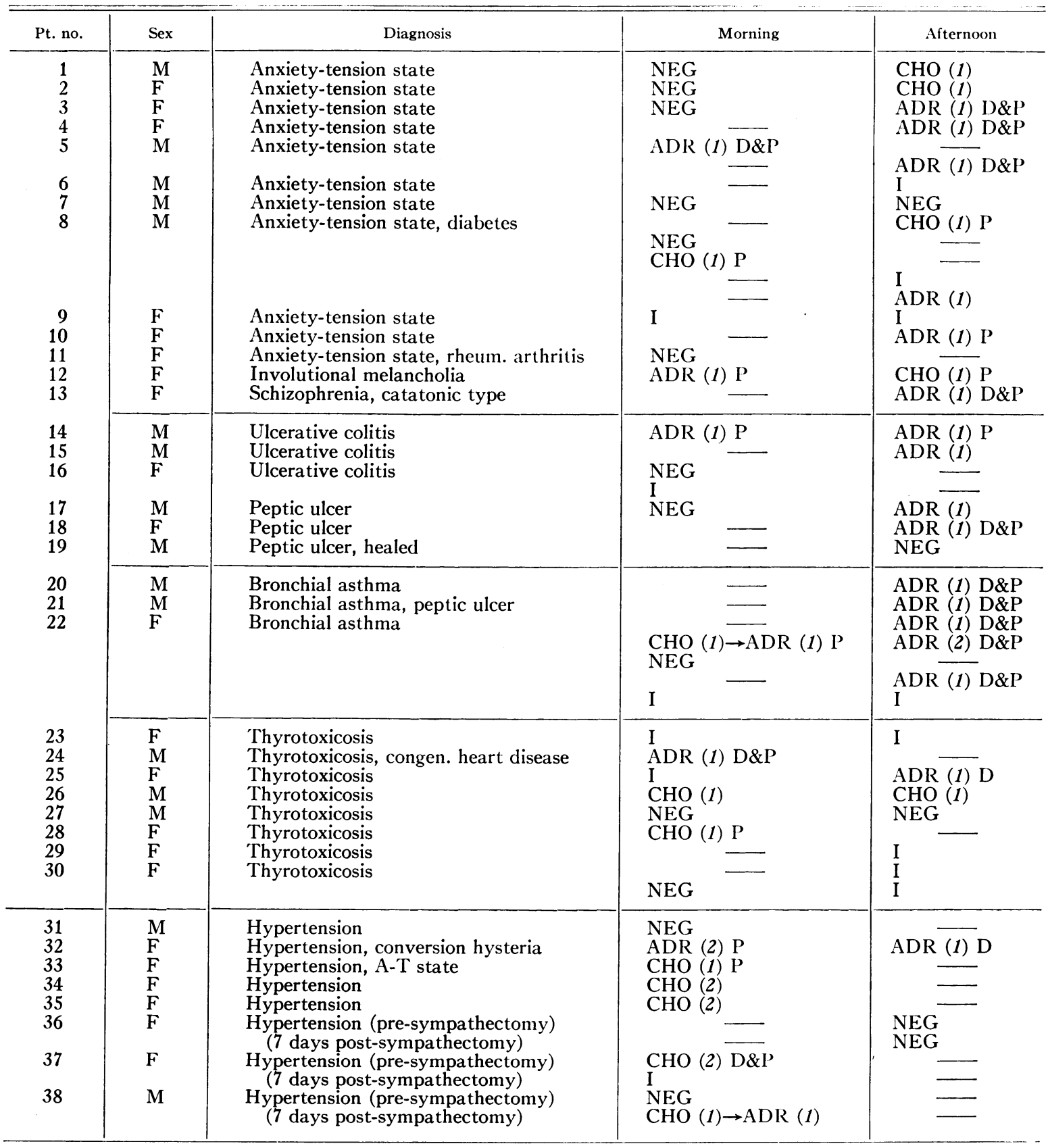

tem in the several diseases studied. The most that can be said is that with the method used there is no significant difference in the effects upon isolated rabbit duodenum of blood taken from normal persons and patients suffering from certain types of chronic emotional disturbances, ulcerative colitis, peptic ulcer, bronchial asthma, thyrotoxicosis, and essential hypertension. It remains entirely possible that in these and other diseases, substances may be present in the blood which are the result of, or are quantitatively altered by, disturbances in autonomic nervous system function. Should such substances be present, it must be concluded that the method under investigation is not capable of consistently demonstrating them.

Asicle from the irregularity and inconsistency 


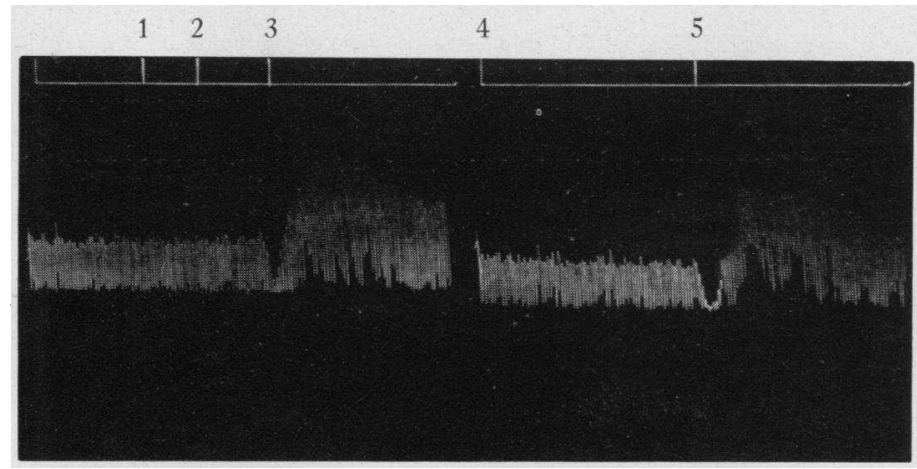

FIG. 8

1. 0.02 cc. pitressin diluted $1: 1000$-no effect.

2. $0.10 \mathrm{cc}$. pitressin diluted $1: 1000$ - no effect.

3. $0.02 \mathrm{cc}$. pitressin undiluted (20 units/cc.) - ADR effect followed by $\mathrm{CHO}$ effect.

4. New Ringer-Tyrode solution. -

5. $0.02 \mathrm{cc}$. pitressin undiluted-same effect as before.

of the results for which no satisfactory explanation is apparent, the very nature of the responses of the muscle to blood was sometimes difficult to interpret. In numerous tests, after the addition of the blood sample, the first effect noted was a transient increase in muscle tone and amplitude of contraction. This was followed by a decrease in tone and amplitude which might be marked and prolonged. This type of response might be interpreted as evidence of the existence of both cholinergic and adrenergic substances in the blood and in our results has been indicated as such.

However, Hoskins (8) observed that the application of epinephrine in a dilution subminimal to that needed to produce a characteristic inhibition of muscular activity would frequently increase the activity of the tissue and often cause an increase in tonus. Thus both types of muscle response might be produced by an adrenergic factor. In our experiments, especially in the initial mixing of blood with the Ringer-Tyrode solution in which the muscle was suspended, some transitory variation in dilution might possibly have occurred and could not have been avoided. It has also been shown that epinephrine appears to have the ability of increasing the synthesis of acetylcholine (9) and of inhibiting cholinesterase activity $(10,11)$. Presumably, under the proper circumstances, this also could result in an alteration of characteristic muscle response.

Reference has been made earlier to the ability of many substances besides acetylcholine to increase the tone and amplitude of contraction of the gut. The response of the duodenal muscle strip to pitres$\sin$ (Figure 8 ) is of interest in this regard. Actually, there is considerable doubt whether acetylcholine is ever present in circulating blood under normal circumstances. Existing in the tissues in a physiologically inactive form, it is activated by nerve impulses but almost immediately destroyed in situ by the enzyme, cholinesterase, which is a normal constituent in blood $(12,13)$. Dale (13) has shown that only in the presence of eserine does acetylcholine appear in a perfusion fluid. Thus it is most unlikely that the "cholinergic" effects noted in this and other similar experiments were due to acetylcholine.

The frequency with which blood caused effects quite different from the solutions of epinephrine and acetylcholine, the marked irregularity and inconsistency of the results, and the uncertainty of the nature of the substances producing the "adrenergic" and "cholinergic" effects raise considerable question as to the significance of the response of isolated rabbit duodenum to blood. It becomes apparent that this method is not a satisfactory means of testing for the presence of truly adrenergic substances in the blood.

\section{CONCLUSIONS}

1. No significant differences were observed in the responses of isolated rabbit intestine to blood from normal, psychoneurotic, and organically ill 
subjects. Marked variability and irregularity of responses were present throughout.

2. Repeated studies on the same subjects showed diurnal as well as day to day variations in effect. These variations did not correlate with the existing emotional status, the influence of environmental factors, or the type or severity of illness.

3 . The irregularity and inconsistency of the results and the uncertainty of the exact nature of the substances in blood having what have been thought to be adrenergic and cholinergic effects upon muscle, cause us to feel that the response of isolated rabbit duodenum to blood is not a satisfactory method of studying autonomic nervous system function.

\section{BIBLIOGRAPHY}

1. Hoskins, R. G., A consideration of some biologic tests for epinephrine. J. Pharmacol. \& Exper. Therap., 1911, 3, 93.

2. Ambache, N., Interaction of drugs and the effect of cooling on the isolated mammalian intestine. J. Physiol., 1946, 104, 266.

3. Dikshit, B. B., Acetylcholine formation by tissues. Quart. J. Exper. Physiol., 1938, 28, 243.

4. Milhorat, A. T., Small, S. M., Doty, E. J., and Bartels, W. E., Probable mechanism by which so- matic changes in certain emotional states are mediated. Proc. Soc. Exper. Biol. \& Med., 1943, 53, 23.

5. Diethelm, O., Doty, E. J., and Milhorat, A. T., Emotions and adrenergic and cholinergic changes in the blood. Arch. Neurol. \& Psychiat., 1945, 54, 110.

6. Bernheim, Fredrick, Interaction of acetylcholine and epinephrine on the isolated small intestines of various animals. J. Pharmacol. \& Exper. Therap., 1934, 51, 59.

7. Cannon, W. B., and de la Paz, D., Emotional stimulation of adrenal secretion. Am. J. Physiol., 1911, 28, 64.

8. Hoskins, R. G., The asthenic effect of epinephrine upon intestine. Am. J. Physiol., 1912, 29, 363.

9. Torda, C., and Wolff, H. G., Effect of epinephrine on the synthesis of acetylcholine. Proc. Soc. Exper. Biol. \& Med., 1944, 56, 88.

10. Benson, Wilbur, The inhibition of cholinesterase by adrenalin. Proc. Soc. Exper. Biol. \& Med., 1948, 68, 598.

11. Waelsch, H., and Rackow, H., Natural and synthetic inhibitors of choline esterase. Science, 1942, 96, 386.

12. Chang, H. C., and Gaddum, J. H., Choline esters in tissue extracts. J. Physiol., 1933, 79, 255.

13. Dale, H., Walter Ernest Dixon memorial lexture; pharmacology and nerve endings. Proc. Roy. Soc. Med., 1935, 28, 319. 